\title{
Factors Affecting Farm Loan Delinquency in the Southeast
}

\author{
Frederick Murdoch Quaye ${ }^{1, *}$, Denis Nadolnyak ${ }^{2} \&$ Valentina Hartarska $^{2}$ \\ ${ }^{1}$ Regions Bank, Birmingham, AL, USA \\ ${ }^{2}$ Department of Agricultural Economics and Rural Sociology, Auburn University, AL, USA \\ *Corresponding author: Regions Bank, Birmingham, AL, USA. E-mail: cnngh@yahoo.com
}

Received: November 19, 2017 Accepted: December 4, 2017 Published: December 20, 2017

doi: 10.5296/rae.v9i4.12165 URL: https://doi.org/10.5296/rae.v9i4.12165

\begin{abstract}
This study examines the factors and behaviors that affect Southeast US farmers' ability to meet their loan repayment obligations within the stipulated loan term. The study uses a 10-year (2003-2012) pooled cross-sectional data from the USDA ARMS survey data (Phase III). A probit approach is used to regress delinquency against various borrower-specific, loan-specific, lender-specific, macroeconomic and climatic variables for the first part.

The results show that farmers with larger farms, farmers with insurance, farmers with higher net income, farmers with smaller debt to asset ratio, farmers with single loans and those that take majority of their loans from sources apart from commercial banks are those that are less likely to be delinquent. Temperature and precipitation also affect outcomes, but by minute magnitudes.
\end{abstract}

JEQ: Q12, Q14, Q55

Keywords: Farm Credit, Credit Delinquency, Climate, Agricultural Insurance, Southeast US 


\section{Introduction}

Agriculture is a high risk activity with farmers continuously facing high level of uncertainty. An array of shocks may affect farmers' incomes and by extension their debt obligations. There may be input and output (e.g. commodity) price variations, pest/disease destruction, flood, hail, etc. Farming is capital intensive enterprise with large amounts of money needed to start or expand operations, buy land, update expensive machinery introduced by fast technological innovations occurring as a result of scarcity of labor, land and other resources. To maintain and grow their operations, farmers need to borrow funds but continuous access to funds is affected by farmers' repayment record and availability of collateral (Hartarska and Nadolnyak, 2012).

Delinquency and default are costly to farmers and their lenders and it is important to understand what factors affect them. We use large individual operator data for the Southeastern region to identify the factors associated with delinquency on agricultural loans. While there are many studies evaluating individual credit risks or predicting default and delinquency for a portfolio of a lender, less work is done to estimate what specific factors affect individual farmer's delinquency for the general population of farmers. This is especially important because there are differences in the profiles of farmers applying for a loan to a specific lender. The two main competing sources of agricultural loans in the US are commercial agricultural banks, and Farm Credit System (FCS) institutions (Dodson et al, 2004). These institutions' clients and their default risks are likely different. Ryan et al (1999) notes that FCS lenders are more likely to serve larger, wealthier, and more established farmers as compared to commercial farms. Analysis of US farm balance sheets shows that FCS provides more real-estate backed loans while commercial banks emphasize operating loans (Hartarska et al and our own computations). Indeed the ARMS data used in this paper collects information about 17 sources of funds to farmers. Thus, while default and delinquency studies evaluate default for a group of borrowers typically in state or industry level, we evaluate what factors affect agricultural borrowers' loan delinquency and default using nationally representative ARMS data for 10-year period.

Recent trends show that delinquency and defaults on agricultural loans extended by commercial banks are among the lowest relative to other loans (Escalante et al, 2016 AFR). Figure 1 shows the US loan delinquency rates from commercial banks over the last four decades. Though delinquency rates for most of the non-agricultural sectors experienced a significant rise, U.S. agriculture maintained the lowest delinquency rate. According to a USDA report, (Shane and Morehart, 2012), the decline in farm delinquency rates in 2010, coupled with high farm income in 2010 and in 2011, indicates that farm loan charge-off rates are moving back towards long term trend levels. However, preventing default remains important and delinquency is costly even in favorable for agriculture conditions. 


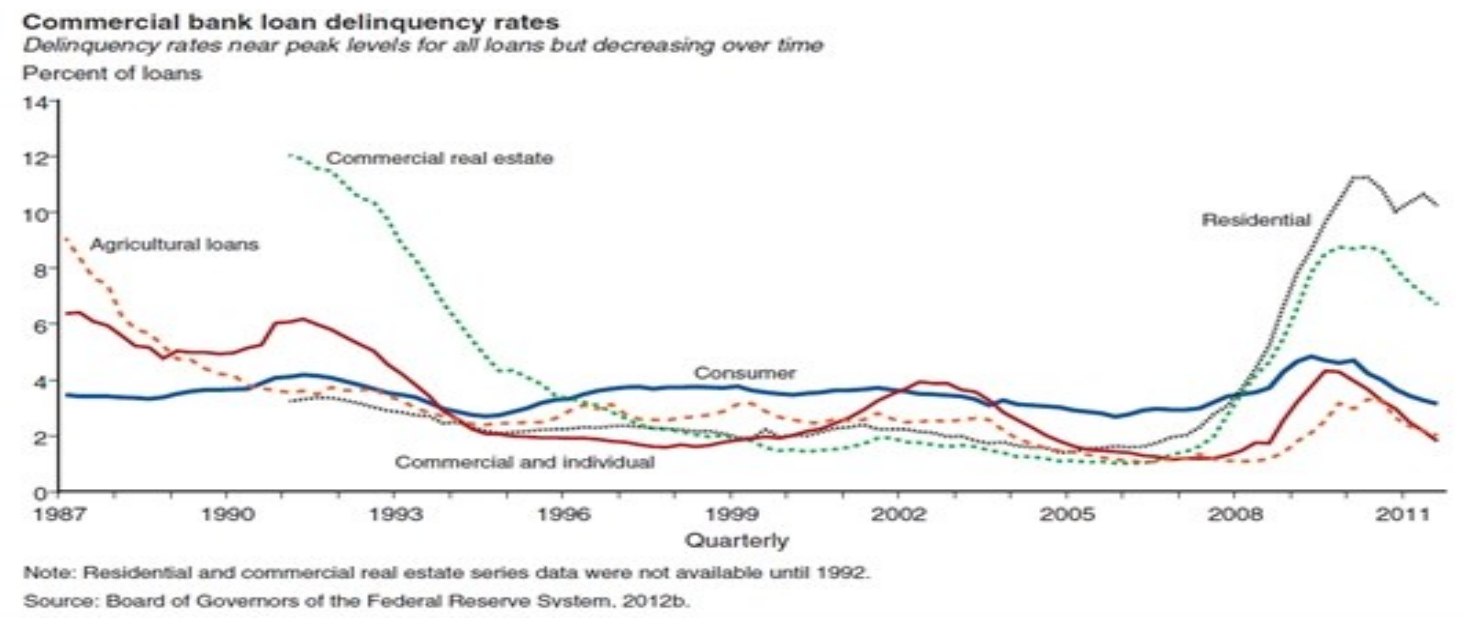

Figure 1. Commercial Banks Loan Delinquency Rates

Factors that affect timely loan repayment vary across sectors and geographical locations, though there may be similarities across the board. These factors are typically classified into four groups: borrower specific characteristics, lender specific characteristics, loan characteristics, and country or regional specific variables of the economic environment. In addition, there are shocks events some of them predictable, that are likely affecting delinquency. Emerging in the literature is a focus on the impact of weather and climate variability (Ayanda, 2012). Extreme erratic climatic conditions resulting in extreme temperature and rainfall reduce yields, expected revenue, and thus the probability of agricultural loan delinquency.

The paper is structured as follows. Related studies are reviewed in the next section. The analytical framework and empirical model used for the analysis are then presented in the third section. Next, the data and estimation procedures are described in the fourth section, followed by the empirical results and subsequent discussion of the results. Lastly, the paper ends with some concluding remarks.

\section{Literature Review}

Default/delinquency is either strategic or related to borrower's ability to pay. Strategic default, occurs when the borrower is better off defaulting rather than repaying the loan. It is well studied for long-term mortgage-backed loans and less so for agricultural loans. The mortgage loan default literature typically uses option based model to predict default alone or default in the context of both default and prepayment decisions while controlling for the ability-to-pay aspects (Hartarska and Gonzalez-Vega, 2006). Strategic default is less important in agricultural loans because land and farming operations are not easily transferable, exit is not comparable to leaving a residential house or strategically defaulting on another loans. This is so because agricultural loans are offered by fewer lenders, and loans are typically secured by 
agricultural land and assets, which is has been relatively stable, except for few episodes both of which are in periods outside of our period of study. In empirical work, the strategic defaults' risk is typically controlled for by controlling for level and fluctuations of the land values.

Non-strategic default is related to the borrower's ability to pay and to shock events, and it has been subject to more studies in the agricultural finance literature. The focus of the research has been on how to prevent default and decrease lender's losses rather than on identifying how shock events and other factors affect borrowers' actions. Studies of farmers' default are limited to borrower type, state or time period due to lack of individual national data. For example, the FCS which extends over a third of all agricultural loans in the US recognizes regional differences and uses region specific models to estimate borrower's credit score. This implies that each region has a single credit scoring model, which is typically representative of the farm type dominant in that region. Individual work also focuses on specific loans/farmers or state/districts (e.g. Featherstone et al. 2006.) Agricultural lenders' measure borrower's ability-to-repay and make lending decisions by evaluating their collateral, financial statements, business plan and borrower credit history. At least in the past, agricultural lenders relied more on loan security, repayment capacity, and solvency than on the farm profitability and financial efficiency. Such systems are understandably imperfect because historical financial information generated under certain conditions may not be applicable in the future and thus affect true repayment capability (Crouhy et al., 2001). More importantly, while the emphasis of collateral has been typical for agricultural lenders, there are emerging arguments and evidence that agricultural lenders are moving away from more collateral based lending and towards more cash-flow based lending practices (Walraven et al., 2004; Klinefelter and Penson, 2005; Hartarska and Nadolnyak, 2012).

Traditionally agricultural finance models of lenders' credit risk and borrower default use use logit/probit estimation techniques (Durguner et al 2007; Miller et al. 1989; and Novak et al 1994). More recent work develops advanced agricultural lending credit risk model (Katchova 2005, Featherstone 2006, Odeh et al 2011). Some of this research was motivated by potential need for agricultural lenders to change their capital requirements under the New Basel Capital Accord. For example, Katchova et al (2005) develop two option-based credit risk models to estimate probability of default, loss given default, and the expected and unexpected losses. They find that results varied substantially depending on the riskiness and granularity of the loan portfolio, which is lender/region specific. Odeh et al (2011) uses a multi-objective evolutionary optimization algorithm and develop a Fuzzy dominance based Simplex Genetic Algorithm to generate decision rules for predicting agricultural loan default. Yan et al (2009) measures credit risk by using a seemingly unrelated regressions to predict farmers' ability in meeting their financial obligations.

Most credit risk evaluation systems capture the ability-to-pay default and assume that shocks events are idiosyncratic to a borrower and thus as long as some sufficient cushion is available, borrowers should be able to repay. Previous default (strategic or not) is recorded in the credit history and is costly because farmers who defaulted on previous loans are less likely to secure another loan from any creditor. Even applicants to the Farm Service Agency, which exists to 
serve exclusively farmers who cannot otherwise get commercial loans, must have good credit history but also must show that previous default was due to circumstances beyond farmer's control or shocks. Exogenous shocks have significant impact on borrowers' repayment of agricultural loans but some of the potential effects may be predictable and or provisioned for. Exogenous factors such as (predictable) changes in prices paid and received by farmers, technological change, interest and exchange rates, land prices and macro-environmental factors such as GDP bring about significant volatility to agricultural incomes (Beckman, 2015). Some of these factors may offset each other but to a limited extent. Deryugina and Hsiang (2014) find that that higher crop prices do not dramatically offset yield losses caused by high temperature day and reductions in yields translate into reductions in farm income. In particular, these authors find that net farm income per capita (in levels) declines by $\$ 21.07$ for each day above $30{ }^{\circ} \mathrm{C}$.

There is emerging evidence on how weather and extreme events measured by various (predictable) indexes affect agricultural loan delinquency and default. For example, Hartarska and Nadolnyak (2012) use simple mean comparison of agricultural banks' portfolio annual performance in various years classified by the Nino 3.4 index, and find that in La Niña years, agricultural banks in the southeastern U.S. have lower charge-offs and extend more and larger loans than in neutral years suggesting a link between the ENSO measures and agricultural loan repayment. Nadolnyak and Hartarska (2013) find that for the period 1999-2010 non-neutral ENSO years are associated with smaller levels of delinquent loans in agricultural commercial banks in the Southeast. These results are attributable to the possibility that farmers' losses in some extreme years may be helped by support mechanisms such as insurance which was not controlled for due to lack of data. A similar work evaluating the link between Farm Credit System Institutions portfolios and ENSO measures of weather variability in the Southeastern US shows that only strong El Nino is associated with higher delinquency rates, while weak and medium El Nino are associated with lower delinquency rates (Nadolnyak, Shen and Hartarska, 2016).

This research controls for insurance use, because there is evidence that crop insurance use is associated with higher default risk (Ifft et al, 2014). These results suggest that for moderate, but not very strong weather shocks, farmers are able to maintain repayment. Moreover, results of Ifft et al 2015 show that farmers use more sort term debt when their business risk (weather related) decreases and vice versa to balance their overall risk (which likely affects portfolio default risk). Overall this line of literature suggests that evaluating the impact of weather on agricultural loans delinquency and default is warranted(Note 1).

Evidence from developing countries where support mechanisms and insurance markets are weak also shows that catastrophic and weather related events affect borrowers. For example, a study of a microfinance institution in Peru showed that borrowers access to (micro) finance serve as an insurance mechanism to help survive the catastrophic events (Collier et al, 2011). Berg and Schrader (2012) study the impact of volcanic eruption on loan default rates and interest rate in Ecuador and find increase in default on loans approved after high volcanic activity. Czura and Klonner (2010) study the effect of December 2004 Indian Ocean Tsunami on credit demand and lending outcomes in ROSCAs in South India. Pelka, Weber and 


\section{Al Macrothink}

Musshoff (2015) find that excessive rain during the harvest period increases credit risk of loans to farmers.

There are both theoretical arguments and evidence that insurance markets' complementary role should be considered in studies of agricultural loan delinquency and default. For example, agricultural insurance companies face moral hazard issue because there is continued supply of credit to farmers even in high production risk areas (Smith et al, 2009) affecting demand for insurance. McKenzie et al (2009) find potential liquidity benefits of making available an Over-the-Counter Margin Credit Swap (MCS) contract to grain hedgers. The MCS was developed as a financing tool that enables hedgers to draw on sources of capital outside the farm credit system during high volatility periods and provide liquidity, thus mitigating delinquency and default. Internationally, Holemans et al (2011) used credit default swap pricing methodology to price weather derivative of South African grape farmers and mitigate possible default issues.

In the climate literature we find that increased incidences of extreme temperatures and rainfall have a high impact in geographical areas that are relatively more affected by the ENSO, one of which is the Southeastern United States (Higgins et al., 2002; Halpert and Ropelewski, 1992).(Note 2) Moreover, crop production in this region is mostly rain-fed, making its agriculture more vulnerable to weather variability and appropriate for a study of the impact of weather on agricultural lenders' portfolios. This is important as Schlenker, Hanemann, and Fisher (2005) argue that irrigation may bias estimates of the impact of climate on agricultural production.

Some studies are beginning to incorporate climate factors to study farmers' incomes. Cai et al (2011) use a dynamic optimization model to simulate how farm-level realized price/profitability responses to yield change were induced by climate change. They observed that reduction in crop yields due to climate change results in reduced farm profitability for most of the states studied, which in turn increases the risk of defaulting on their payment. They also suggest that predicted climate change is more likely to pose a problem for agricultural production and profitability in the Southern U.S. states relative to the rest of the US states.

\section{Data and Method}

We use a binary probit model to determine which factors affects farmer loan delinquency in Southeastern US. The empirical strategy controls for strategic default/delinquency and ability to pay (credit risk) factors but also incorporates the influence external shocks in particular weather and macroeconomic environment.

In this paper, the probability of observing delinquency is modeled as:

(4) $D=\boldsymbol{X}_{i}^{\prime} \beta+\varepsilon_{i}$ 
Where $D$ represents the loan delinquency, $X_{i}$ refers to borrower specific variables, loan specific variables, lender specific variables, macroeconomic variables, and climate variables. $\beta_{i}$ represents the estimable parameters whilst $\varepsilon_{i}$ represents the error term, which is assumed to be distributed as standard normal and has a variance of 1 .

The empirical work is focused on the Southeastern US because it most affected by long-term climate variability and because agriculture there predominantly mainly rain fed so the shock events impact can captured. Farmer characteristics and loan data come from the Agricultural Resource Management Survey (ARMS) annual surveys database (Phase III). ARMS is USDA's primary source of information on the financial condition, production practices, and resource use of America's farm businesses and farm households. A ten-year period (2003 2012) survey data of the ARMS are combined into a pooled cross section. The data contains borrower specific, loan specific and lender specific variables. The survey questions collects information as of December, $31^{\text {st }}$ of the current year.

Weather data comes from the Global Historical Climatology Network (GHCND) monthly summaries and include the temperature and precipitation and databases under the National Climatic Data Center (NCDC) for the corresponding crop growth year. We use county levels weather data. We add county unemployment rates and income data from the US Census Bureau. The sample includes only farmers who had one loan to eliminate money fungilibity issues for farmers with multiple loans. Since not all farmers have loans during the 10-year pooled-cross sectional ARMS data, we end up with 8,966 observations after cleaning.

The ARMS data does not contain detailed information of loan delinquency or default. We construct delinquency measure in the following manner. We focus on medium term loans (with a term of 10 years or less) and on loans with less than 3 years from origination for less than 3 years. From each individual loan, we compute the year in which the loan should be repaid using the origination year and the term of the loan. Next, we establish if the loan was repaid and classify it as non-delinquent. If there is a balance but the current year is before the year in which it should have been repaid the loan is classified as non-delinquent. The loan is classified as delinquent if it has an outstanding balance and the due year is before the current year. We do not have information if this loan may be in fact restructured but assume that it was restructured because the farmer has had difficulty repaying. To ensure reasonable timeframe work for the delinquency, we construct two samples. In the first sample we include farmers that have been delinquent within 3 years before the survey year, that is, the due year is within the past 3 years in order not to capture delinquent loans that were restructured several years back, because farmers' circumstances and the economic and climatic environments might have changed significantly. We further restrict the sample to loans with an original term of 3 years or less (about $67 \%$ of the loans, with $33 \%$ loans having maturity larger than 3 years) to create another subsample of delinquent shorter term loans. This procedure would miss loans that were given within past 3 years which became delinquent but might have been restructured in the meantime or are still being paid off. Our constructs may also contain some recollection error. We assume that all possible measurement error are in the left hand side variable and are nonsystematic therefore, with sufficient number of 


\section{Macrothink}

observation are will not lead to biased results.

\subsection{Empirical Analysis}

Table 1 presents the summary statistics of the variables used in the regressions. The summary statistics indicate that there is a wide range in the variables capturing farmer and farm characteristic, indicating a variety of sampled farms ranging from small farms to very large farms. We do not find significant outliers in most of the variables. Continuous predictor variables mainly show a normal distribution.

Summary statistics show that out of the 5,433 farmer observations with 1 loan, $3.72 \%$ are classified as delinquent; $64.8 \%$ of the respondents have only one loan, whilst $21.62 \%, 6.97 \%$, $2.64 \%$ and $3.96 \%$ have two, three, four and five different loans respectively. For those with only one loan, $2.78 \%$ of the farmers are delinquent. Those with two and three loans have $4.04 \%$ and $1.95 \%$ delinquency rates, whilst from the farmers with four and five loans $5.9 \%$ and $1.5 \%$ respectively are delinquent.

Table 1. Summary Statistics

\begin{tabular}{lcc}
\hline Variable & Mean & Std. Dev. \\
\hline & 54 & 11 \\
Operator Age & 7.6 & 1.6 \\
Acres (owned in ‘100) & 24.2 & 13.7 \\
Farm Age & 160 & $1,277.29$ \\
Net Farm Income ('1000) & 3.7 & 18.9 \\
Delinquency for all (\%) & 414 & 1,198 \\
Debt (\$1,000) & 23 & 50 \\
Debt to asset ratio (\%) & 2,438 & $11,100$. \\
Assets (\$1,000) & 2,046 & 10,900 \\
Net Worth (\$1000) & 206 & 997 \\
Payment Capacity (coverage ratio (\$1,000) & 6.66 & 4.93 \\
Average Interest rate (\%) & 411 & $1,168$. \\
Total loan balance (\$1000) & 1.59 & 1.01 \\
Number of Loans & & \\
& 8.77 & 3.16 \\
Unemployment rate (\%) & 20,277 & 4,347 \\
Per-Capita Income (\$) & 61.6 & 5.02 \\
Average Temperature (F) & 50.63 & 10.7 \\
Precipitation (F) & 18.17 & \\
Return on Assets & 2.13 & \\
Asset Turnover Ratio & 1.10 & \\
Tenure (Land used over land owned) & & \\
\hline
\end{tabular}


The dataset contains 17 different sources of loans. The five main sources of loans (making up approximately $94 \%$ of the loans) are Commercial banks (51.4\%), Farm Credit System (29.9\%), Implement dealers and financing corporations (IDFC) (6.7\%), Savings and loan associations/ residential mortgage lenders (SLA) (3.1\%), and lastly the Farm Service Agency $(2.9 \%)$, in descending order. Commercial bank loans have $3.8 \%$ delinquency rate, while slightly more $-4.1 \%$ of FCS loans were delinquent; $0.8 \%$ of IDFC loans were delinquent; $3.0 \%$ of SLA borrowers and $1.3 \%$ of FSA borrowers were delinquent. Among those farmers with delinquent loans, farmers aged 55 - 64 have the highest delinquency rate $(4.2 \%)$, followed by those between the ages $45-54(3.7 \%)$, those between $35-44(3.9 \%), 65$ and older $(3.3 \%)$, borrowers below 35 years of age $(1.5 \%)$. In the Apendix we also show the cross tabulation summary statistics, as well as data on delinquencies by southeastern states. The delinquent rates are approximately spread across the states, with the exception North Carolina and Kentucky which have very small number of delinquent farmers.

\section{Regression Results}

The regression results for the delinquency model are presented in two folds. First and of prime focus are the results shown in Tables 2. Table 2 presents the results for the regression of the probit model, where account selection problems have been accounted for. The first two columns of Table 2 present the results for both crop and livestock farmers, whilst the last two columns present the results for only crop farmers. As explained earlier (in order to control for possible dependent variable measurement errors including money fungibility), the first and third columns include farmers that have either been delinquent for 3 years or less, whilst the second and fourth columns comprise of farmers that have been delinquent for 3 years or less, and also had their loans within the past three years before the survey. The Chi square tests show that each of the estimated models is jointly significant.

The results for the correction model based on the probit heckman selection approach are used for the purpose of this discussion. This takes into consideration that farmers that had access to loans may themselves be selected. The selection variables used include farm income, farmer age, organic matter content of soil (for soil quality), financial debt and farm size.

The results show that age is a significant factor in predicting the delinquent behavior of farmers. Older farmers are less likely to be delinquent as compared to their younger counterparts. Education, however does not show significant impacts with regards to which categories of farmers are more likely to be delinquent than the other. Both variables for farm size and farming experience meet the apriori expectation, where an increase in the number of acres operated reduces the probability of becoming delinquent, and likewise an increase in the years of farming experience also decreases the likelihood of being delinquent. Increases in net farm income as strongly expected reduces the probability of a farmer becoming delinquent, a key variable reflected in most of the variables used by agricultural credit institutions to access whether or not to grant loans to individual farmers. 
Table 2. Average Marginal Effects from a Probit of Delinquency, for all farm types and for crops only with weather controls version corrected (/1000 or 100 as appropriate and as indicated)

\begin{tabular}{|c|c|c|c|c|}
\hline \multirow{2}{*}{$\begin{array}{l}\text { Marginal Effects } \\
\text { Delinquent }\end{array}$} & \multicolumn{2}{|c|}{ All } & \multicolumn{2}{|c|}{ Crops Only } \\
\hline & +3 & $+3 /-3$ & +3 & $+3 /-3$ \\
\hline \multirow[t]{2}{*}{ Acres ('100) } & $-6.86 * * *$ & $-2.14 *$ & $-8.65 * *$ & 5.39 \\
\hline & $(2.19)$ & $(1.38)$ & $(3.04)$ & $(72.9)$ \\
\hline \multirow[t]{2}{*}{ Farming Experience } & $-0.0001 * *$ & -0.0002 & $-0.001 *$ & -0.0002 \\
\hline & $(0.000)$ & $(0.000)$ & $(0.0004)$ & $(0.0032)$ \\
\hline \multirow[t]{2}{*}{ Farm Income ('000) } & $-1.54 * * *$ & $-0.755^{*}$ & $-0.473 * *$ & $-0.534^{*}$ \\
\hline & $(0.577)$ & $(0.441)$ & $(0.176)$ & $(0.323)$ \\
\hline \multirow[t]{2}{*}{ Financial Debt ('000) } & 9.51 & $11.2 * *$ & $30.9 * * *$ & 21.8 \\
\hline & $(8.29)$ & $(8.08)$ & $1.08)$ & $(76.7)$ \\
\hline \multirow[t]{2}{*}{ Assets ('000) } & $-3.04 *$ & $-1.74 *$ & $-2.49 * *$ & $-1.26 * *$ \\
\hline & $(1.7)$ & $(0.87)$ & $(1.07)$ & $(0.54)$ \\
\hline \multirow[t]{2}{*}{ Debt-to-Asset ratio (\%) } & 0.247 & 0.644 & -0.834 & -0.924 \\
\hline & $(0.757)$ & $(0.402)$ & $(2.930)$ & $(2.510)$ \\
\hline \multirow[t]{2}{*}{ Rate of return (\%) } & $-0.021 * *$ & -0.013 & $-0.576 * * *$ & $-0.109 *$ \\
\hline & $(0.008)$ & $(0.009)$ & $(0.020)$ & $(0.0721)$ \\
\hline \multirow[t]{2}{*}{ Net Worth } & -3.06 & $-3.13^{*}$ & $-18.1 * *$ & 6.85 \\
\hline & $(2.43)$ & $(2.14)$ & $(6.34)$ & $(4.55)$ \\
\hline \multirow[t]{2}{*}{ Insurance $(\%)$} & 0.475 & 1.53 & $-1.46^{*}$ & $-1.86 * *$ \\
\hline & $(0.418)$ & $(0.476)$ & $(0.819)$ & $(0.497)$ \\
\hline Repayment capacity & 1.16 & 0.730 & -1.55 & $-6.23 *$ \\
\hline$(\%)$ & $(0.942)$ & $(0.872)$ & $(5.45)$ & $(0.05)$ \\
\hline Interest Rate on loan & 0.074 & $0.039^{*}$ & 0.0123 & $0.854 * *$ \\
\hline$(\%)$ & $(0.099)$ & $(0.010)$ & $(0.431)$ & $(0.182)$ \\
\hline Prime bank loan rate & -0.226 & $6.40 * *$ & 0.120 & $5.28 * *$ \\
\hline$(\%)$ & $(0.211)$ & $(27.6)$ & $(0.423)$ & $(0.949)$ \\
\hline \multirow[t]{2}{*}{ Loan Term } & $-0.0008 * * *$ & $-0.001 * * *$ & -0.001 & -0.046 \\
\hline & $(0.0002)$ & $(0.0004)$ & $(0.044)$ & $(0.038)$ \\
\hline \multirow[t]{2}{*}{ Loan Outstanding ('1000) } & -12.1 & $3.91 * *$ & $35.4 * *$ & 18.0 \\
\hline & $(6.44)$ & $(1.79)$ & $(12.4)$ & $(19.3)$ \\
\hline
\end{tabular}


Per capita income

Unemployment (\%)

Lender types $($ Base $=$

Commercial banks)

FCS

FSA

IDFC

Co-Ops

Other

$\begin{array}{cc}0.003 & 0.005^{*} \\ (0.004) & (0.002) \\ 0.009 & 0.016 \\ (0.015) & (0.020)\end{array}$

$(0.542)$

$-0.226^{* *}$

(0.099)

(1.15)

$-0.402$

$(0.590)$

$-0.276$

2017, Vol. 9, No. 4

Purchase Contract

$-0.015^{* *}$

(0.007)

$-0.01^{*}$

$-0.001$

(0.065)

$(0.001)$

$-0.005$

$-0.003 *$

$(0.0175)$

(0.002)

0.036

$(0.010)$

$-0.025 * * *$

(0.005)

$0.029 * *$

$-0.008$

0.006

(0.010)

(0.005)

(0.020)

$-0.01$

$-0.003$

(0.007)

(0.010)

\section{Controls}

Age categories

Gender

Education

Loan Purpose

State

Weather (non liner

temperature and climate)

Constant

Yes
Yes
Yes
Yes
Yes
No
No

$-12.29 *$

(8.3)

Yes

Yes

Yes

Yes

Yes

No

No

$-38.11 * *$

(18.7)

Yes

Yes

Yes

Yes

Yes

Yes

Yes

$-59.33 * *$

(23.4)

Yes

Yes

Yes

Yes

Yes

Yes

Yes

-45.80 *

(29.9)

Observations
Log likelihood
Pseudo $\mathrm{R}^{2}$
Model chi-square
Prob $>\mathbf{C h i}^{2}$

3268

1370

1041

477

$-402.8$

$-112.4$

$-116.6$

$-39.01$

0.496

0.366

0.419

0.688

196.7

129.7

167.9

172.2

0.000

0.000

0.000

0.000 


\section{Mll Macrothink}

Southeastern farmers with higher rates of return have lesser probabilities of becoming delinquent. The results further show that farmers that made expenses on insurance have a lesser likelihood of becoming delinquent, an indicator that the credit markets are working quite efficiently as elaborated in the credit literature. Crop farmers with higher maximum repayment capability index are less likely to be delinquent, in accordance to the apriori expectation. As expected, the interest rates on loans as well as the prime rates have a positive correlation with farmers' likelihood to be delinquent, whilst increases in the terms of loans for farmers increases their ability to repay (though not significant for only crop farmers). Farmers that borrow from FCS and FSA are less likely to be delinquent as compared to those that that borrow from commercial banks. Those that borrow from the IDFC are also less likely to be delinquent compared to their counterparts that borrow from commercial banks. With the assumption that farmers that have single loans use the loans for the specific reasons for which they received the loan, the results show that farmers that took the loan to purchase feeder livestock are more likely to be delinquent compared with those that took the loans for farm improvement/ rehabilitation. On the other hand, farmers that took the loans for either purchasing other kinds of livestock or for paying for operational costs are less likely to be delinquent compared to those that used their loans for farm improvement/ rehabilitation.

Quantitatively, the following discussion shows by how much the factors affect delinquency (second column results). From the marginal effect results of Table 2 (which present the results for the delinquency model when selection is corrected for), we observe that an increase in farm size by 100 acre decreases the probability of a farmer becoming delinquent by a magnitude of 2.14. A thousand dollar increase in a farmers' income also decreases the probability of becoming delinquent by 0.75 . A thousand dollar increase in farm debt increases the probability of delinquency by 11.2. A thousand dollar increase in the value of assets that a farmer owns decreases the probability of becoming delinquent by 1.74 . The results further indicate that agricultural insurance helps reduce the likelihood of delinquency. Farmers with insurance are $1.86 \%$ less probable to be delinquent than farmers without insurance (column 4 results for crops only). An additional year in a loan term of a farmer decreases the probability of becoming delinquent by 0.001 . On the contrary, an additional thousand dollar of loan outstanding increases the probability for a farmer to become delinquent by 3.91. Finally, we observe that both temperature and rainfall significantly affect credit delinquency, but by very minute magnitudes $(<0.00001)$ per unit weather changes. This may be because other are much more responsible for credit delinquency, other than the weather variables. Table 3 provides a robust analysis for the estimations performed. 


\section{IIMacrothink}

Table 3. Marginal Effects (from a Probit Estimation) of Delinquency Model for Farmers with Multiple Loans (Robustness check)

\begin{tabular}{|c|c|c|}
\hline Delinquent & All $(+3 /-3)$ & Crops $(+3 /-3)$ \\
\hline \multirow[t]{2}{*}{ Acres } & $-0.309 * *$ & 0.904 \\
\hline & $(0.105)$ & $(0.578)$ \\
\hline \multirow[t]{2}{*}{ Farming Experience } & 0.000192 & $-0.00213 * *$ \\
\hline & $(0.000366)$ & $(0.00136)$ \\
\hline \multirow[t]{2}{*}{ Farm Income ('1000) } & $-0.296^{* * *}$ & -0.756 \\
\hline & $(0.0507)$ & $(0.483)$ \\
\hline \multirow[t]{2}{*}{ Financial Debt ('000) } & 0.271 & $0.0841 *$ \\
\hline & $(0.204)$ & $(0.0504)$ \\
\hline \multirow[t]{2}{*}{ Debt-to-Asset ratio } & $0.0166^{*}$ & -0.0760 \\
\hline & $(0.00758)$ & $(0.486)$ \\
\hline \multirow[t]{2}{*}{ Rate of return } & 0.0919 & -0.670 \\
\hline & $(0.105)$ & $(4.28)$ \\
\hline \multirow[t]{2}{*}{ Assets } & -0.0144 & $-0.0311 * *$ \\
\hline & $(0.0231)$ & $(0.0128)$ \\
\hline \multirow[t]{2}{*}{ Net Worth } & -0.00651 & $-0.0429 *$ \\
\hline & $(0.0122)$ & $(0.0274)$ \\
\hline \multirow[t]{2}{*}{ Insurance } & $-0.00366 * *$ & $-0.0264 *$ \\
\hline & $(0.00119)$ & $(0.0171)$ \\
\hline \multirow{2}{*}{$\begin{array}{l}\text { Maximum Repayment } \\
\text { capacity }\end{array}$} & -0.00520 & -0.0259 \\
\hline & $(0.0119)$ & $(0.166)$ \\
\hline \multirow[t]{2}{*}{ Average interest rate } & $0.0388 * *$ & $0.0213 *$ \\
\hline & $(0.0192)$ & $(0.0136)$ \\
\hline \multirow[t]{2}{*}{ Prime bank loan rate } & -0.00175 & $0.0572 * * *$ \\
\hline & $(0.00472)$ & $(0.00366)$ \\
\hline \multirow[t]{2}{*}{ Average term } & $-0.0375 * * *$ & -0.00301 \\
\hline & $(0.00564)$ & $(0.0192)$ \\
\hline \multirow[t]{2}{*}{ Total Loan Outstanding } & $0.00504 * * *$ & $0.145 * *$ \\
\hline & $(0.00162)$ & $(0.0626)$ \\
\hline \multirow{2}{*}{\multicolumn{3}{|c|}{$\begin{array}{l}\text { Number of loans }(\text { Base }=\text { One } \\
\text { loan) }\end{array}$}} \\
\hline & & \\
\hline \multirow[t]{2}{*}{2 Loans } & $0.0224 * * *$ & $0.00766 * * *$ \\
\hline & $(0.00158)$ & $(0.00377)$ \\
\hline \multirow[t]{2}{*}{3 Loans } & $0.0226 * * *$ & $0.0206 * * *$ \\
\hline & $(0.00321)$ & $(0.00608)$ \\
\hline \multirow[t]{2}{*}{4 Loans } & $0.0272 * * *$ & \\
\hline & $(0.00154)$ & \\
\hline \multirow[t]{2}{*}{5 Loans } & $0.142 * * *$ & $0.0251 * * *$ \\
\hline & $(0.0310)$ & $(0.00718)$ \\
\hline
\end{tabular}




\section{Lender Type ( $\mathrm{B}=$ Commercial banks) \\ FCS}

FSA

IDFC

Co-ops

Other

Per capita income

Unemployment

\section{Controls}

Age categories

Gender

Education

State

Weather (non1 liner

temperature and climate)
$-0.00732$

(0.0120)

0.00954

(0.0403)

$-0.0489 *$

$(0.0323)$

0.0469

$(0.186)$

$-0.655^{* *}$

(0.321)

$-0.000168$

(0.00151)
000165

(0.106)

$-0.0389 * * *$

$(0.00142)$

0.352

(0.477)
$-0.113 * * *$
$(0.00720)$
$-0.0326 * * *$
$(0.00208)$

No

Yes

No

No Yes

Yes Yes

Yes Yes

$$
\begin{aligned}
& \text { Standard errors in parentheses } \\
& * * * \mathrm{p}<0.01, * * \mathrm{p}<0.05, * \mathrm{p}<0.1
\end{aligned}
$$

\section{Conclusion}

This paper attempts to examine the factors and behaviors that affect Southeast US farmers' ability to meet their loan payment obligations within the stipulated loan term. A delinquent farmer is defined as one whose loan term is overdue by at least a year and have yet still not finalized payments. The study uses a 10-year (2003-2012) pooled cross-sectional data from the USDA ARMS survey data. These years have similar variables to aid in calculating the delinquency variable, and also have common variables needed for the estimations. A probit approach is used to regress delinquency against various borrower-specific, loan-specific, lender-specific, macroeconomic and climatic variables for the first part.

When corrected for selection bias, the results show that age is a significant factor and older farmers are less likely to be delinquent than their younger counterparts. Farmers with bigger farms and those with more years of farming experience are both less likely to be delinquent. Expectedly, farmers with higher net farm income tend to pay their loans more on time comparatively. Farmers with insurance, and those with higher rates of return have a smaller probability of being delinquent. The results also show that farmers with higher debt to asset ratio are more likely to be delinquent. In addition, the results show that farmers with just a 
single loan are less likely to be delinquent compared with those with multiple loans. Famers who acquire chunk of their loans from commercial banks are also in general more likely to be delinquent, compared with other borrowers. Rainfall and temperature both affect farmer's credit delinquency, but by very minute magnitudes.

\section{References}

Ayanda, I.F., \& Ogunsekan, O. (2012). Farmers' Perception of Repayment of Loans Obtained from Bank of Agriculture. Journal of Agricultural Science, 3(1), 21-27. https://doi.org/10.1080/09766898.2012.11884681

Beckman, J., \& Schimmelpfennig, D. (2015). Determinants of farm income, Agricultural Finance Review, 75(3), 385-402. https://doi.org/10.1108/AFR-06-2014-0019

Berg, G., \& Schrader, J. (2012). Access to credit, natural disasters, and relationship lending. Journal of Financial Intermediation, 21(4), 549-568. https://doi.org/10.1016/j.jfi.2012.05.003

Cai, R., Bergstrom, J. C., Mullen, J. D., \& Wetzstein, M. E. (2011). Assessing the Effects of Climate Change on Farm Production and Profitability: Dynamic Simulation Approach. Paper presented at the Agricultural \& Applied Economics Association's AAEA \& NAREA Joint Annual Meeting, Pittsburgh, Pennsylvania, July 24-26, 2011.

Collier, B., Katchova, A., \& Skees, J. (2011). Loan portfolio performance and El Nino, an intervention analysis. Agricultural Finance Review, 71(1), 98-119. https://doi.org/10.1108/00021461111128183

Crouhy, M., Galai, D., \& Mark, R. (2001). Risk Management. New York: McGraw-Hill, USA.

Czura, K., \& Klonner, S. (2010). The Tsunami and the Chit Fund-Evidence from the Indian Ocean Tsunami Hit on Credit Demand in South India, Proceedings of the German Development Economics Conference, Hannover 2010 46, Verein für Socialpolitik, Research Committee Development Economics.

Deryugina, T., \& S. M. Hsiang. (2014). NBER Working Paper 20750 (NBER, 2014).

Dodson, C. B., \& Koenig, S. R. (2004). Competition in Farm Credit Markets: Identifying Market Segments Served by the Farm Credit System and Commercial Banks. Agricultural Finance Review, 64(2), 167-186. https://doi.org/10.1108/00214660480001161

Durguner, S., \& Katchova, A. L. (2007). Credit Scoring Models in Illinois by Farm Type: Hog, Dairy, Beef and Grain. Paper Presented at the American Agricultural Economics Association Meeting, Portland, Oregon, July 29-August 1, 2007.

Escalante, C., Song, M., \& Dodson, C. (2016). FSA farm loan repayment under economic recession and drought conditions: Evidence from US Southeastern and Midwestern 
farms, Agricultural Finance Review, 76(4), 445-461, https://doi.org/10.1108/AFR-07-2016-0063

Featherstone, A. M., Roessler, L.M., \& Barry, P. J. (2006). Determining the Probability of Default and Risk Rating Class for Loans in the Seventh Farm Credit District Portfolio. Review of Agricultural Economics, 28, 4-23. https://doi.org/10.1111/j.1467-9353.2006.00270.x

Halpert, M.S., \& Ropelewski, C.F. (1992). Surface Temperature Patterns Associated with the Southern Oscillation. Journal of Climate, 5, 577-593. https://doi.org/10.1175/1520-0442(1992)005\%3C0577:STPAWT\%3E2.0.CO;2

Hartarska, V., \& Gonzalez-Vega, C. (2006). What Affects New and Established Firms' Expansion? Evidence from Small Firms in Russia, Small Business Economics, 27, 195-206. https://doi.org/10.1007/s11187-006-0012-0

Hartarska, V., \& Nadolnyak, D. (2012). El Niño and Agricultural Lending in the Southeastern U.S.A. Southern Business and Economics Journal, 35(1\&2).

Higgins, R. W., Kousky, V. E.,Kim, H.K.,Shi, W., \& Unger, D. (2002). High frequency and trend adjusted composites of United States temperature and precipitation by ENSO phase. NCEP/ Climate Prediction Center ATLAS No. 10.

Holemans, N., van Vuuren, G., \& Styger, P. (2011). Pricing Weather Derivatives for the Chardonnay Cultivar in Wellington using a Credit Default Swap Methodology. Agrekon: Agricultural Economics Research, Policy and Practice in Southern Africa, 50(4), 25-44. https://doi.org/10.1080/03031853.2011.617903

Ifft, J., Kuethe, T., \& Morehart, M. (2013). Farm Debt Use by Farms with Crop Insurance. Choices, 3rd Quarter.

Ifft, J., Novini, A., \& Patrick, K. (2014). Debt Use by US Farm Businesses. USDA-ERS.

Economic Information Bulletin, (103). USDA-ERS Economic Information Bulletin, (122).

Ifft, J., Kuethe, T., \& Morehart, M. (2015). Does federal crop insurance lead to higher farm debt use? Evidence from the Agricultural Resource Management Survey (ARMS). Agricultural Finance Review, 75, 349-367. https://doi.org/10.1108/AFR-06-2014-0017

Katchova, A.L., \& P.J. Barry. (2005). Credit Risk Models and Agricultural Lending. American Journal of Agricultural Economics, 87, 194-205. https://doi.org/10.1111/j.0002-9092.2005.00711.x

Klinefelter, D., \& J. Penson. (2005). Growing Complexity of Agricultural Lending Decisions. Choices, 20(1).

McKenzie, A. M., \& Kunda, E. L. (2009). Managing Price Risk in Volatile Grain Markets, Issues and Potential Solutions. Journal of Agricultural and Applied Economics, 41(2), 353-362. https://doi.org/10.1017/S1074070800002832 
Miller, L. H., \& LaDue, E. L. (1989). Credit Assessment Models for Farm Borrowers: A Logit Analysis. Agricultural Finance Review, 49, 22-36.

Nadolnyak, D., \& V. Hartarska. (2013). Agricultural Disaster Payments in the Southeast U.S.: Do weather and climate variability matter? Applied Economics, 44(33). https://doi.org/10.5539/ijef.v8n12p238

Nadolnyak, D., Shen, X., \& Hartarska, V. (2016). Climate Variability and Agricultural Loan Delinquency in the US. International Journal of Economics and Finance, 8(12), 238-249. https://doi.org/10.5539/ijef.v8n12p238

Novak, M. P., \& LaDue, E. L. (1994). An Analysis of Multi-period Agricultural Credit Evaluation Models for New York Dairy Farms. Agricultural Finance Review, 54, 55-65.

Odeh, O., Koduru, P., Featherstone, A., Das, S., \& Welch, S. M. (2011). A multi-objective approach for the prediction of loan defaults. Expert System Applications, 38(7), 8850-8857. https://doi.org/10.1016/j.eswa.2011.01.096

Pelka, N., Musshoff, O., \& Weber, R. (2015). Does weather matter? How rainfall affects credit risk in agricultural microfinance. Agricultural Finance Review, 75(2), 194-212. https://doi.org/10.1108/AFR-10-2014-0030

Ryan, J. T., \& Koenig S. R. (1999). Who Holds Farm Operator Debt? Special article in Agricultural Income and Finance 76:47S52. Pub. No.AIS-76, USDA/Economic Research Service, Washington, DC.

Schlenker, W. W., Hanemann, M., \& Fisher, A. C. (2005). Will U.S. Agriculture Really Benefit from Global Warming? Accounting for Irrigation in the Hedonic Approach. American Economic Review, 95(1), 395-406. https://doi.org/10.1257/0002828053828455

Shane, M., \& Morehart, M. (2012). Economic and Financial Conditions Bode Well for U.S. Agriculture. Agricultural Baseline Projections, USDA, ERS.

Smith, V. H., \& Watts, M. (2009). Index Based Agricultural Insurance in Developing Countries: Feasibility, Scalability and Sustainability. Prepared for the Bill and Melinda Gates Foundation.

Walraven, N., \& Barry, P. J. (2004). Bank Risk Ratings and the Pricing of Agricultural Loans." Agricultural Finance Review, 64(2), 107-118. https://doi.org/10.1108/00214660480001157

Yan, Y., Barry, P., Paulson, N., \& Schnitkey, G. (2009). Measurement of Farm Credit Risk: SUR Model and Simulation Approach. Paper presented at the Agricultural \& Applied Economics Association AAEA \& ACCI Joint Annual Meeting, Milwaukee, WI, July 26-28, 2009. 
Notes

Note 1. Another issue that has attracted attention is whether farmers' use of crop insurance affects credit default and use of debt. Ifft et al. (2013) found that farms participating in crop insurance have higher default risk (but the study does not control for factors that affect both insurance participation and debt use. Ifft el al (2015) use a propensity score matching to study if debt use varies by crop insurance participation. They find that farmers' participation in crop insurance is affecting their short term debt use but not long term debt use which interpreted as consistent as risk balancing as farmers increase (decrease) their financial risk when their business risk improves(worsens).

Note 2. Other regions of the world most affected by ENSO are southeast Africa, southeast Asia, and the coastal areas of South and Central America

\section{Copyright Disclaimer}

Copyright for this article is retained by the author(s), with first publication rights granted to the journal.

This is an open-access article distributed under the terms and conditions of the Creative Commons Attribution license (http://creativecommons.org/licenses/by/3.0/). 